\title{
Killer Whales (Orcinus orca) Sighted West of Ni'ihau, Hawai' $i^{1}$
}

\author{
Joseph R. Mobley 7r., ${ }^{2}$ Lori Mazzuca, ${ }^{3}$ Alison S. Craig, ${ }^{4}$ Michael W. Newcomer, ${ }^{5}$ and \\ Scott S. Spitz ${ }^{4}$
}

\begin{abstract}
A rare sighting of five killer whales (Orcinus orca), including one juvenile, occurred on 20 March 2000 during an aerial survey of waters west of the Hawaiian island of Ni'ihau. The sighting occurred ca. $11 \mathrm{~km}$ west of Kamalino Bay on Nicihau, at $21^{\circ} 49^{\prime} \mathrm{N}, 160^{\circ} 20^{\prime} \mathrm{W}$. Killer whales are not unknown in Hawaiian waters, but the most recent confirmed sighting on record for Hawaiian waters was in 1979.
\end{abstract}

ON $20 M_{\text {ARCH }} 2000$ during an aerial survey of marine mammals in Hawaiian waters, four large delphinids and one juvenile were sighted approximately $11 \mathrm{~km}$ west of Kamalino Bay on $\mathrm{Ni}^{\prime}$ ihau $\left(21^{\circ} 49^{\prime} \mathrm{N}, 160^{\circ} 20^{\prime} \mathrm{W}\right)$ in waters approximately $1830 \mathrm{~m}$ (1000 fathoms) deep. The animals were circled for 7 min at an altitude of $244 \mathrm{~m}$, during which time two photographs (Figure 1) were obtained through a belly window using a Pentax 645 camera with a 206-mm lens. Simultaneously, altitude measurements were obtained with a radar altimeter (Collins 50A). Positive identification of species at the time of sighting was hampered by glare. One observer (M.W.N.) commented that the animals appeared "unusually robust." In the absence of positive identification, the sighting was recorded as "unidentified delphinids."

Subsequent inspection of the photographs revealed clear diagnostic features of killer whales (Orcinus orca), including evidence of white eye patches on three individuals, white anus patch on two individuals, a relatively tall dorsal fin on one individual, and light gray saddle marking behind the dorsal fin of one

\footnotetext{
${ }^{1}$ Manuscript accepted 30 October 2000.

2 Social Sciences, University of Hawai' $\mathrm{i}-$ West $\mathrm{O}^{6} \mathrm{ahu}$, 96-129 Ala Ike, Pearl City, Hawaíi 96782.

${ }^{3}$ National Marine Mammal Laboratory, 7600 Sand Point Way NE, Seattle, Washington 98115-0070.

${ }^{4}$ Kewalo Basin Marine Mammal Laboratory, 1129 Ala Moana Boulevard, Honolulı, Hawaíi 96814.

522371 Hartman Drive, Los Altos, California 94024.
}

Pacific Science (2001), vol. 55, no. 3:301-303 (C) 2001 by University of Hawai'i Press All rights reserved individual. The clearest diagnostic feature evident in the photographs was the characteristic wide, paddle-shaped flippers that are almost as wide as they are long (Leatherwood et al. 1988). Leatherwood et al. (1988) noted that killer whales can sometimes be confused with false killer whales (Pseudorca crassidens) and Risso's dolphins (Grampus griseus). However, the paddle-shaped flippers distinguish them from both of these species, and the dark coloration and larger body size $(\leq 9 \mathrm{~m})$ distinguish them from Risso's dolphins $(\leq 4 \mathrm{~m})$. By knowing the precise altitude via the radar altimeter, combined with the use of a calibrated camera system, we were able to apply standard photogrammetric techniques (Baker 1960, Perryman and Lynn 1993) to the two photographs. We estimated that the adults ranged in length from approximately 4.7 to $6.5 \mathrm{~m}$, and the juvenile was approximately $3.8 \mathrm{~m}$ in length.

In the first photograph, the four adults were arranged two abreast, with the juvenile trailing behind. In the second photograph, taken several minutes later, the adults were spread farther apart and the juvenile appeared to be swimming either canted to one side or inverted (based on the greater proportion of white coloration) just behind and below the right pectoral flipper of the largest adult. It is likely that this adult was a male, due to the larger flippers and flukes (Dahlheim and Heyning 1999).

Killer whales are not unknown in Hawaiian waters, but are sufficiently rare to be worthy of note. The earliest record appeared in the Honolulu Star-Bulletin of 26 February 1938 (cited in Tomich 1986), which described a sighting off Olowalu, Maui. Because 


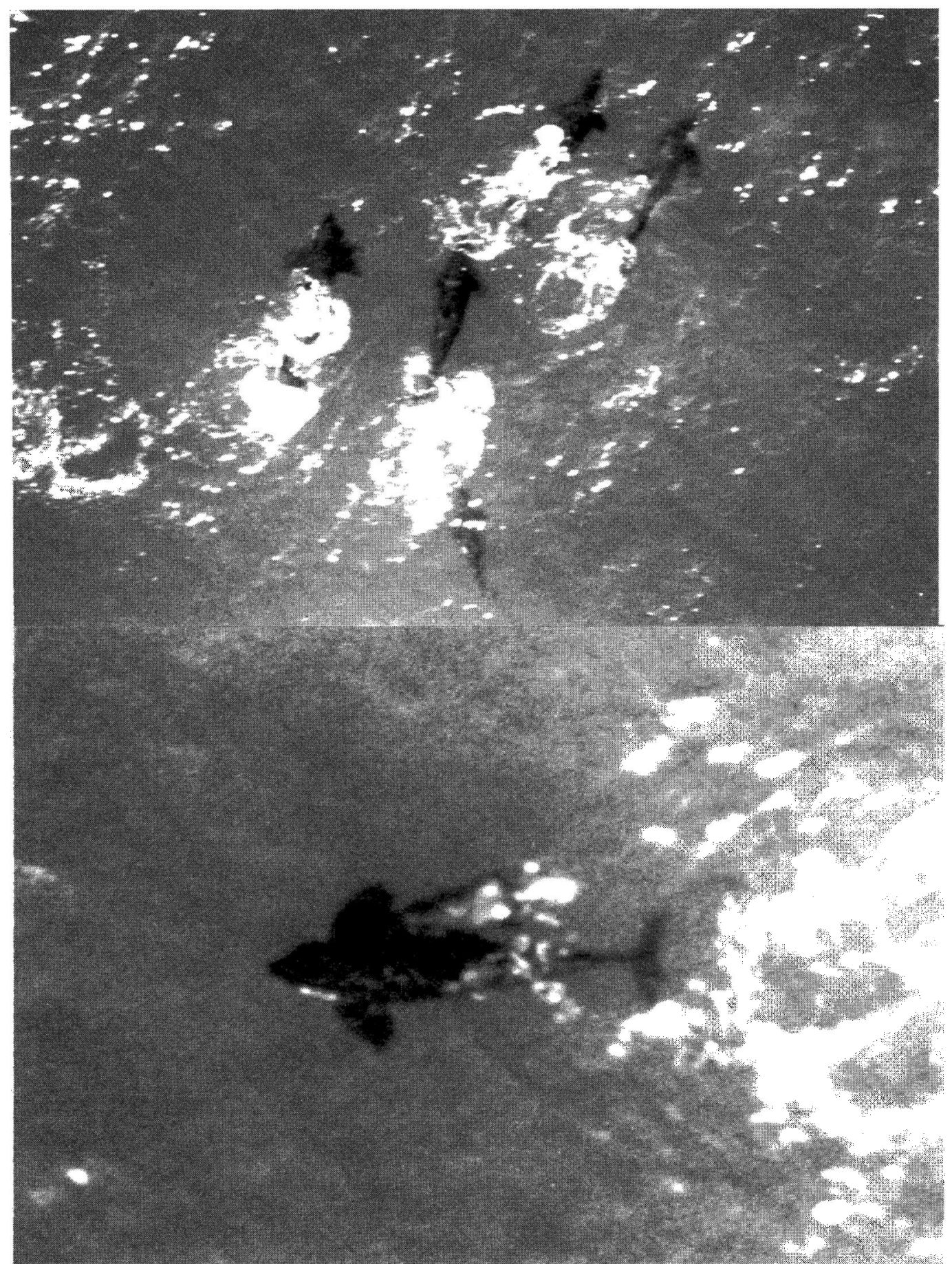

FIguRE 1. Top. The four adult killer whales as they were first sighted on 20 March 2000 , with the juvenile trailing behind (bottom center). The adult farthest left is presumed to be male, based on the size of the paddle-shaped flippers and tall dorsal fin. Bottom. An enlargement of a second photograph showing the male with the juvenile swimming behind the right-hand flipper. 
photographs were not included in the report, verification of species is uncertain. Richards (1952) examined photographs of an animal stranded on 25 January 1950 at South Point, Hawai $i$, and identified it as a male killer whale. Shallenberger (1981) reported sightings of killer whales off the Wai'anae coast of the island of O'ahu in January 1978 by a University of Hawai'i research vessel, and a sighting of killer whales observed and photographed by observers aboard the Easy Rider near Kaua'i in December 1979. Evering (1980) provided photographs and a more detailed description of the latter sighting. Tomich (1986:79) noted, "Such sporadic sightings suggest that the killer whale is not resident in Hawaiian waters, but merely passes through from time to time, probably from cooler regions to the north." The fact that the sighting reported here was the only sighting of killer whales during $4 \mathrm{yr}$ of aerial surveys of all major Hawaiian Islands (1993, 1995, 1998, and 2000), encompassing more than 27,000 nautical miles of effort, reinforces the notion that these whales are not usually sighted in Hawaiian waters.

It is interesting to note that all of the sightings mentioned here occurred during the winter season (December-February), largely overlapping with the presence of wintering humpback whales in Hawaiian waters. Corkeron and Connor (1999:1234) recently theorized that the primary benefit of migration of baleen whales to tropical waters during the winter breeding season is the reduced risk of predation by killer whales. Those authors also noted the possibility that, during the winter breeding season, some "mammal-eating killer whales [may] follow the whale migrations to feed on this seasonal abundance of neonates."

Killer whales are widely distributed throughout the eastern North Pacific, but are most commonly found in higher latitude waters (Leatherwood et al. 1988). Leatherwood et al. (1988:116) noted that although "records are rare from the vicinity of Hawaii ... the year-round presence of some killer whales makes it worth looking for them at all seasons throughout their entire range, from the ice edge to the equator."

\section{ACKNOWLEDGMENTS}

We extend our appreciation to Janice Waite, Sue Moore, and Marilyn Dahlheim of the National Marine Mammal Laboratory for reviewing our photographs. Thanks also to Gene Wilke, our pilot. The 2000 survey effort was sponsored by an award from the Hawaiian Island Humpback Whale National Marine Sanctuary, as well as the Low Frequency Active Program of the U.S. Navy.

\section{Literature Cited}

Baker, W. H. 1960. Elements of photogrammetry. Ronald Press, New York.

Corkeron, P. J., and R. C. Connor. 1999. Why do baleen whales migrate? Mar. Mamm. Sci. 15:1228-1245.

Dahlheim, M. E., and J. E. Heyning. 1999. Killer whale (Orcinus orca) (Linnaeus, 1758). Pages 281-322 in S. H. Ridgway and R. Harrison, eds. Handbook of marine mammals. Vol. 6. The second book of dolphins and the porpoises. Academic Press, San Diego.

Evering, G. 1980. Orcas sighted in Hawaii. Hawaii Humpback 1 (3): 16, 51.

Leatherwood, S., R. R. Reeves, W. F. Perrin, and W. E. Evans. 1988. Whales, dolphins and porpoises of the eastern North Pacific and adjacent Arctic waters. Dover Publications, New York.

Perryman, W. L., and M. S. Lynn. 1993. Identification of geographic forms of common dolphin (Delpbinus delpbis) from aerial photogrammetry. Mar. Mamm. Sci. 9:119-137.

Richards, L. P. 1952. Cuvier's beaked whale from Hawaii. J. Mammal. 33:255.

Shallenberger, E. W. 1981. The status of Hawaiian cetaceans. Final Report to U.S. Marine Mammal Commission. Report No. MMC77/23, 80 pp. (Available from National Technical Information Service, U.S. Department of Commerce, Springfield, Virginia 22151.)

Tomich, P. Q. 1986. Mammals in Hawai' $i$, 2nd ed. Bishop Museum Press, Honolulu, Hawai $i$. 